UDC 539.3

\title{
STRESS-STRAIN STATE OF THICK-WALLED ANISOTROPIC CYLINDRICAL SHELLS UNDER THERMAL POWER LOAD, PROTECTED BY THE FUNCTIONALLY GRADED MATERIAL
}

\author{
M.P. Semenyuk ${ }^{1}$, \\ Dr. Eng. \\ V.M. Trach', \\ Dr. Eng. \\ A.V.Podvornyi ${ }^{2}$, \\ $\mathrm{PhD}$ (Engineering) \\ ${ }^{1}$ Institute of Mechanics of the National Academy of Sciences of Ukraine, Kyiv, \\ Petra Nesterova str.,3, 02000
}

${ }^{2}$ National University of Water and Environmental Engineering, Rivne, Soborna str., 11, 33028

DOI: $10.32347 / 2410-2547.2020 .105 .165-178$

In the article the stress-strain state of thick-walled structurally anisotropic composite cylindrical shells under thermal power load, which are protected by a functionally graded material, are analysed. Based on the interrelations of the spatial theory of elasticity, a system of inhomogeneous differential equations in three-dimensional formulation, which describes the stress-strain state of thick-walled anisotropic cylindrical shells, was obtained. To reduce the dimensionality of this system, the Bubnov-Galerkin analytical method was used. Thus, the obtained one-dimensional system of twelve equations of normal Cauchy form was implemented using the numerical method of discrete orthogonalization. To represent the possibilities of the proposed approach, there were used stress-strain states of two, four and five-layered anisotropic cylindrical shells of fibrous composites, protected from temperature by a layer of transversely isotropic functionally graded material.

Key words: thick-walled anisotropic cylindrical shell, stress-strain state, three-dimensional formulation, functionally graded material.

\section{Introduction}

Thin-walled structures made of composite materials are widely used in a variety of elements of up-to-date equipment. For example, the aerospace and rocket industries require the use of shells made of lightweight, high-strength composite materials. Unfortunately, traditional composite materials are not always able to be used in high temperatures, because their load-bearing capacity can be significantly reduced. Heat-resistant ceramics can be used to protect thin-walled composites from temperatures, but it is well known that this material has brittle properties and does not bend and twist.

Relatively recently, a new class of composite materials known as functionally graded materials (FGMs) has emerged [16]. Typical FGMs is an inhomogeneous composite made of different phases of material components (usually ceramics and metal). FGMs ceramic components are able to withstand high-temperature environments due to the better heat resistance characteristics, and metal components provide higher mechanical properties and reduce the

(C) Semenyuk M.P., Trach V.M., Podvornyi A.V. 
possibility of destruction. Thus, the use of FGMs can help to protect the shell structure from the effects of variable temperature fields, which will allow the structure to absorb the load without reducing its strength, for instance.

At present, a sufficiently detailed analysis of the stress-strain state of thinwalled and thick-walled cylindrical shells of both conventional composites and FGMs in the calculations of two-dimensional systems under the thermal power load $[1,3,12,15,16,17]$ is made. In this paper, the change of the characteristics of the stress-strain state in the thickness of the structure is modeled by hypotheses of varying degrees of accuracy. It is generally known that to calculate the stress-strain state of thick-walled cylindrical shells it should be applied an approach [2, 6, 7, 10,11,13], based on the use of equations of the spatial theory of elasticity and which allows you to correctly analyze changes of parameters such as stress-strain state of the construction by the thickness.

The authors propose an approach to the establishment of the stress-strain state of a thick layered anisotropic cylindrical shell made of a fibrous composite, which is made at an angle to the generatrix, and a layer of FGMs. It is also necessary to take into account the effect of anisotropy caused by the discrepancy between the directions of reinforcement and the shell axes (Fig. 1) $[1,2,3,6,7,10,11,13,14]$, and to assess the impact of temperature on such a combined structure thickness.

In this paper a three-dimensional theory of elasticity is used to solve the

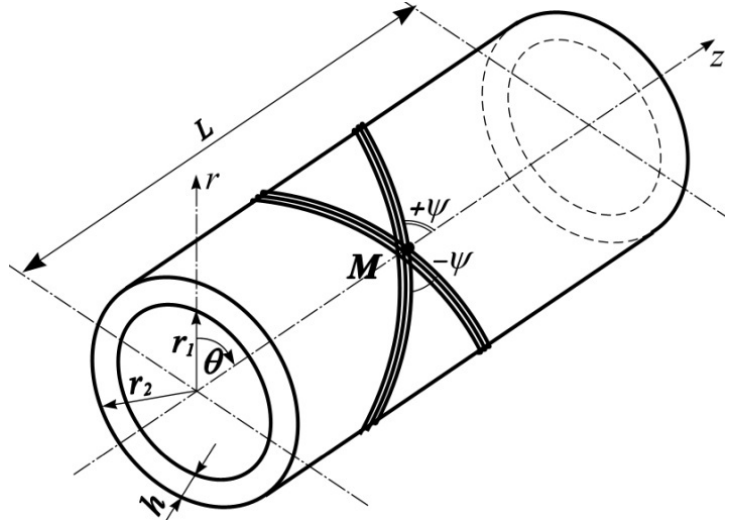

Fig. 1. Cylindrical thick-walled anisotropic shell problem of the stressstrain state of a thickwalled anisotropic cylindrical shell made of fibrous composites [5]. The obtained solutions can serve as references in the calculations of stressstrain states of thinwalled structures of more complex geometry established, for example, when using the finite element method.

\section{Formulation of the problem}

Linear equilibrium equations in non-axisymmetric stress-strain state for each i-th layer are as follows [5]:

$$
\frac{\partial \sigma_{r r}^{i}}{\partial r}=-\frac{1}{r}\left[\sigma_{r r}^{i}+r \frac{\partial}{\partial z}\left(\tau_{z r}^{i}\right)+\frac{\partial}{\partial \theta}\left(\tau_{\theta r}^{i}\right)-\sigma_{\theta \theta}^{i}+r F_{r}^{i}\right] ;
$$




$$
\begin{gathered}
\frac{\partial \tau_{r z}^{i}}{\partial r}=-\frac{1}{r}\left[\tau_{r z}^{i}+r \frac{\partial}{\partial z}\left(\sigma_{z z}^{i}\right)+\frac{\partial}{\partial \theta}\left(\tau_{\theta z}^{i}\right)+r F_{z}^{i}\right] ; \\
\frac{\partial \tau_{r \theta}^{i}}{\partial r}=-\frac{1}{r}\left[\tau_{r \theta}^{i}+\tau_{\theta r}^{i}+r \frac{\partial}{\partial z}\left(\tau_{z \theta}^{i}\right)+\frac{\partial}{\partial \theta}\left(\sigma_{\theta \theta}^{i}\right)+r F_{\theta}^{i}\right],
\end{gathered}
$$

where $r_{i}(i=1,2)$ - radius of the cylinder, which does not depend on the coordinates $z$ and $\theta ; \sigma_{z z}^{i}, \sigma_{r r}^{i}, \sigma_{\theta \theta}^{i}, \tau_{r z}^{i}, \tau_{r \theta}^{i}, \tau_{z \theta}^{i}$ - components of the stress tensor, $F_{r}, F_{z}, F_{\theta}$ - vector projections of specific volume forces on the directions tangent to the coordinate lines $r, z, \theta$.

The relationship between the components of deformation and displacement will take the form:

$$
\begin{gathered}
e_{z z}^{i}=\frac{\partial u_{z}^{i}}{\partial z} ; e_{\theta \theta}^{i}=\frac{1}{r} \frac{\partial u_{\theta}^{i}}{\partial \theta}+\frac{1}{r} u_{r}^{i} ; e_{r r}^{i}=\frac{\partial u_{r}^{i}}{\partial r} \\
e_{z \theta}^{i}=\frac{\partial u_{\theta}^{i}}{\partial z}+\frac{1}{r} \frac{\partial u_{z}^{i}}{\partial \theta} ; e_{r z}^{i}=\frac{\partial u_{r}^{i}}{\partial z}+\frac{\partial u_{z}^{i}}{\partial r} ; e_{r \theta}^{i}=\frac{\partial u_{\theta}^{i}}{\partial r}-\frac{1}{r} u_{\theta}^{i}+\frac{1}{r} \frac{\partial u_{r}^{i}}{\partial \theta} .
\end{gathered}
$$

And $u_{z}^{i}, u_{\theta}^{i}, u_{r}^{i}$ - displacement in the direction of the axes $z, \theta, r$ respectively; $e_{z z}^{i}, e_{\theta \theta}^{i}, e_{r r}^{i}$ - relative linear deformations in the directions of the coordinate axes $z, \theta, r ; e_{z \theta}^{i}, e_{r z}^{i}, e_{r \theta}^{i}$ - relative tangential displacements at the point to the corresponding coordinate surfaces.

The ratios of the generalized Hooke's law, which connect the components of deformations and stresses, when the axes of orthotropy with the coordinate axes are coincident:

$$
\begin{gathered}
e_{z z}^{i}=a_{11}^{i /} \sigma_{z z}^{i}+a_{12}^{i /} \sigma_{\theta \theta}^{i}+a_{13}^{i /} \sigma_{r r}^{i} ; \\
e_{\theta \theta}^{i}=a_{12}^{i /} \sigma_{z z}^{i}+a_{22}^{i /} \sigma_{\theta \theta}^{i}+a_{23}^{i /} \sigma_{r r}^{i} ; \\
e_{r r}^{i}=a_{13}^{i /} \sigma_{z z}^{i}+a_{23}^{i /} \sigma_{\theta \theta}^{i}+a_{33}^{i /} \sigma_{r r}^{i} ; \\
e_{r \theta}^{i}=a_{44}^{i /} \tau_{r \theta}^{i} ; \quad e_{r z}^{i}=a_{55}^{i /} \tau_{r z}^{i} ; \quad e_{z \theta}^{i}=a_{66}^{i /} \tau_{z \theta}^{i} .
\end{gathered}
$$

When rotating the axes of orthotropy relative to the $z$ axis, these dependencies take the form:

$$
\begin{gathered}
e_{z z}^{i}=a_{11}^{i} \sigma_{z z}^{i}+a_{12}^{i} \sigma_{\theta \theta}^{i}+a_{13}^{i} \sigma_{r r}^{i}+a_{16}^{i} \tau_{z \theta}^{i} ; \\
e_{\theta \theta}^{i}=a_{12}^{i} \sigma_{z z}^{i}+a_{22}^{i} \sigma_{\theta \theta}^{i}+a_{23}^{i} \sigma_{r r}^{i}+a_{26}^{i} \tau_{z \theta}^{i} ; \\
e_{r r}^{i}=a_{13}^{i} \sigma_{z z}^{i}+a_{23}^{i} \sigma_{\theta \theta}^{i}+a_{33}^{i} \sigma_{r r}^{i}+a_{36}^{i} \tau_{z \theta}^{i} ; \\
e_{r \theta}^{i}=a_{44}^{i} \tau_{r \theta}^{i}+a_{45}^{i} \tau_{r z}^{i} ; e_{r z}^{i}=a_{45}^{i} \tau_{r \theta}^{i}+a_{55}^{i} \tau_{r z}^{i} ; \\
e_{z \theta}^{i}=a_{16}^{i} \sigma_{z z}^{i}+a_{26}^{i} \sigma_{\theta \theta}^{i}+a_{36}^{i} \sigma_{r r}^{i}+a_{66}^{i} \tau_{z \theta}^{i} .
\end{gathered}
$$

In the equations $(3,4) a_{k l}^{i /}$ and $a_{k l}^{i}$ - are mechanical constants of the $i$-th layer of orthotropic material and material with one plane of elastic symmetry, the relationship between which is established in [4]. 


\section{Research methodology}

The relation of the generalized Hooke's law for a material with one plane of elastic symmetry (4) takes the form [2], which is used in the solution of the system (1):

$$
\begin{aligned}
& \sigma_{z z}^{i}=b_{11}^{i} e_{z z}^{i}+b_{12}^{i} e_{\theta \theta}^{i}+b_{16}^{i} e_{z \theta}^{i}+c_{1}^{i} \sigma_{r r}^{i}+\beta_{11}^{i} T ; \\
& \sigma_{\theta \theta}^{i}=b_{12}^{i} e_{z z}^{i}+b_{22}^{i} e_{\theta \theta}^{i}+b_{26}^{i} e_{z \theta}^{i}+c_{2}^{i} \sigma_{r r}^{i}+\beta_{22}^{i} T ; \\
& \tau_{z \theta}^{i}=b_{16}^{i} e_{z z}^{i}+b_{26}^{i} e_{\theta \theta}^{i}+b_{66}^{i} e_{z \theta}^{i}+c_{3}^{i} \sigma_{r r}^{i}+\beta_{12}^{i} T ; \\
& e_{r r}^{i}=-c_{1}^{i} e_{z z}^{i}-c_{2}^{i} e_{\theta \theta}^{i}-c_{3}^{i} e_{z \theta}^{i}+c_{4}^{i} \sigma_{r r}^{i}+\alpha_{33}^{i} T+a_{13}^{i} \beta_{11}^{i} T+a_{23}^{i} \beta_{22}^{i} T+a_{36}^{i} \beta_{12}^{i} T ; \\
& e_{r z}^{i}=a_{45}^{i} \tau_{r \theta}^{i}+a_{55}^{i} \tau_{r z}^{i}+\alpha_{13}^{i} T ; \\
& e_{r \theta}^{i}=a_{44}^{i} \tau_{r \theta}^{i}+a_{45}^{i} \tau_{r z}^{i}+\alpha_{23}^{i} T,
\end{aligned}
$$

where $b_{k l}^{i}(k, l=1,2,6), c_{k}^{i}(k=1 \div 4)$ - are the characteristics of the $i$-th layer that are determined by the mechanical constants $a_{k l}^{i}$ of the shell material; $\beta_{11}^{i}$, $\beta_{22}^{i}, \quad \beta_{12}^{i}$ - are the components of the stress-strain state of the $i$-th layer, related with the temperature dependences $T\left({ }^{0} \mathrm{~K}\right)$ :

$$
\begin{aligned}
& \beta_{11}^{i} T=-\left(b_{11}^{i} \alpha_{11}^{i}+b_{12}^{i} \alpha_{22}^{i}+b_{16}^{i} \alpha_{12}^{i}\right) T ; \\
& \beta_{22}^{i} T=-\left(b_{12}^{i} \alpha_{11}^{i}+b_{22}^{i} \alpha_{22}^{i}+b_{26}^{i} \alpha_{12}^{i}\right) T ; \\
& \beta_{12}^{i} T=-\left(b_{16}^{i} \alpha_{11}^{i}+b_{26}^{i} \alpha_{22}^{i}+b_{66}^{i} \alpha_{12}^{i}\right) T .
\end{aligned}
$$

In this system of equations and in (5) $\alpha_{i j}^{i}(i, j=1 \div 3)$ - are the coefficients of linear thermal expansion of the material of the $i$-th shell layer.

Replacing in (5) the deformations $e_{z z}^{i}, e_{\theta \theta}^{i}, e_{z \theta}^{i}$ by their expressions from (2) and substituting the obtained dependences for $\sigma_{z z}^{i}, \sigma_{\theta \theta}^{i}, \tau_{z \theta}^{i}$ in (1), and for $e_{r z}^{i}, e_{r \theta}^{i}, e_{r r}^{i}$ in (2) we obtain for each $i$-th layer a complete system of differential equations in partial derivatives, in which we take into account that the shell is deformed according to the axial symmetry:

$$
\begin{aligned}
& \frac{\partial \sigma_{r r}^{i}}{\partial r}=\frac{c_{2}^{i}-1}{r} \sigma_{r r}^{i}-\frac{\partial \tau_{r z}^{i}}{\partial z}+\frac{b_{22}^{i}}{r^{2}} u_{r}+\frac{b_{12}^{i}}{r} \frac{\partial u_{z}^{i}}{\partial z}+\frac{b_{26}^{i}}{r} \frac{\partial u_{\theta}^{i}}{\partial z}-\frac{b_{12}^{i}}{r} \alpha_{11}^{i} T-\frac{b_{22}^{i}}{r} \alpha_{22}^{i} T- \\
& -\frac{b_{26}^{i}}{r} \alpha_{12}^{i} T ; \\
& \frac{\partial \tau_{r z}^{i}}{\partial r}=-c_{1}^{i} \frac{\partial \sigma_{r r}^{i}}{\partial z}-\frac{1}{r} \tau_{r z}^{i}-\frac{b_{12}^{i}}{r} \frac{\partial u_{r}^{i}}{\partial z}-b_{11}^{i} \frac{\partial^{2} u_{z}^{i}}{\partial z^{2}}-b_{16}^{i} \frac{\partial^{2} u_{\theta}^{i}}{\partial z^{2}}+b_{11}^{i} \alpha_{11}^{i} \frac{d T}{d z}+ \\
& +b_{12}^{i} \alpha_{22}^{i} \frac{d T}{d z}+b_{16}^{i} \alpha_{12}^{i} \frac{d T}{d z} ;
\end{aligned}
$$




$$
\begin{aligned}
& \frac{\partial \tau_{r \theta}^{i}}{\partial r}=-\frac{2}{r} \tau_{r \theta}^{i}-b_{66}^{i} \frac{\partial^{2} u_{\theta}^{i}}{\partial z^{2}}-c_{3}^{i} \frac{\partial \sigma_{r r}^{i}}{\partial z}-\frac{b_{26}^{i}}{r} \frac{\partial u_{r}^{i}}{\partial z}-b_{16}^{i} \frac{\partial^{2} u_{z}^{i}}{\partial z^{2}}+b_{16}^{i} \alpha_{11}^{i} \frac{d T}{d z}+ \\
& +b_{26}^{i} \alpha_{22}^{i} \frac{d T}{d z}+b_{66}^{i} \alpha_{12}^{i} \frac{d T}{d z} \\
& \frac{\partial u_{r}^{i}}{\partial r}=c_{4}^{i} \sigma_{r r}^{i}-\frac{c_{2}^{i}}{r} u_{r}^{i}-c_{1}^{i} \frac{\partial u_{z}^{i}}{\partial z}-c_{3}^{i} \frac{\partial u_{\theta}^{i}}{\partial z}+\alpha_{33}^{i} T-a_{13}^{i} b_{11}^{i} \alpha_{11}^{i} T-a_{13}^{i} b_{12}^{i} \alpha_{22}^{i} T- \\
& -a_{13}^{i} b_{16}^{i} \alpha_{12}^{i} T-a_{23}^{i} b_{12}^{i} \alpha_{11}^{i} T-a_{23}^{i} b_{22}^{i} \alpha_{22}^{i} T-a_{23}^{i} b_{26}^{i} \alpha_{12}^{i} T-a_{36}^{i} b_{16}^{i} \alpha_{11}^{i} T- \\
& -a_{36}^{i} b_{26}^{i} \alpha_{22}^{i} T-a_{36}^{i} b_{66}^{i} \alpha_{12}^{i} T ; \\
& \frac{\partial u_{z}^{i}}{\partial r}=a_{55}^{i} \tau_{r z}^{i}+a_{45}^{i} \tau_{r \theta}^{i}-\frac{\partial u_{r}^{i}}{\partial z}+\alpha_{13}^{i} T ; \\
& \frac{\partial u_{\theta}^{i}}{\partial r}=a_{45}^{i} \tau_{r z}^{i}+a_{44}^{i} \tau_{r \theta}^{i}+\frac{1}{r} u_{\theta}^{i}+\alpha_{23}^{i} T .
\end{aligned}
$$

If the temperature field is constant to the cylinder surface, the system (6) will be rewritten:

$$
\begin{aligned}
& \frac{\partial \sigma_{r r}^{i}}{\partial r}=\frac{c_{2}^{i}-1}{r} \sigma_{r r}^{i}-\frac{\partial \tau_{r z}^{i}}{\partial z}+\frac{b_{22}^{i}}{r^{2}} u_{r}+\frac{b_{12}^{i}}{r} \frac{\partial u_{z}^{i}}{\partial z}+\frac{b_{26}^{i}}{r} \frac{\partial u_{\theta}^{i}}{\partial z}-\frac{b_{12}^{i}}{r} \alpha_{11}^{i} T-\frac{b_{22}^{i}}{r} \alpha_{22}^{i} T- \\
& -\frac{b_{26}^{i}}{r} \alpha_{12}^{i} T ; \\
& \frac{\partial \tau_{r z}^{i}}{\partial r}=-c_{1}^{i} \frac{\partial \sigma_{r r}^{i}}{\partial z}-\frac{1}{r} \tau_{r z}^{i}-\frac{b_{12}^{i}}{r} \frac{\partial u_{r}^{i}}{\partial z}-b_{11}^{i} \frac{\partial^{2} u_{z}^{i}}{\partial z^{2}}-b_{16}^{i} \frac{\partial^{2} u_{\theta}^{i}}{\partial z^{2}} ; \\
& \frac{\partial \tau_{r \theta}^{i}}{\partial r}=-\frac{2}{r} \tau_{r \theta}^{i}-b_{66}^{i} \frac{\partial^{2} u_{\theta}^{i}}{\partial z^{2}}-c_{3}^{i} \frac{\partial \sigma_{r r}^{i}}{\partial z}-\frac{b_{26}^{i}}{r} \frac{\partial u_{r}^{i}}{\partial z}-b_{16}^{i} \frac{\partial^{2} u_{z}^{i}}{\partial z^{2}} ; \\
& \frac{\partial u_{r}^{i}}{\partial r}=c_{4}^{i} \sigma_{r r}^{i}-\frac{c_{2}^{i}}{r} u_{r}^{i}-c_{1}^{i} \frac{\partial u_{z}^{i}}{\partial z}-c_{3}^{i} \frac{\partial u_{\theta}^{i}}{\partial z}+\alpha_{33}^{i} T-a_{13}^{i} b_{11}^{i} \alpha_{11}^{i} T-a_{13}^{i} b_{12}^{i} \alpha_{22}^{i} T- \\
& -a_{13}^{i} b_{16}^{i} \alpha_{12}^{i} T-a_{23}^{i} b_{12}^{i} \alpha_{11}^{i} T-a_{23}^{i} b_{22}^{i} \alpha_{22}^{i} T-a_{23}^{i} b_{26}^{i} \alpha_{12}^{i} T-a_{36}^{i} b_{16}^{i} \alpha_{11}^{i} T- \\
& -a_{36}^{i} b_{26}^{i} \alpha_{22}^{i} T-a_{36}^{i} b_{66}^{i} \alpha_{12}^{i} T ; \\
& \frac{\partial u_{z}^{i}}{\partial r}=a_{55}^{i} \tau_{r z}^{i}+a_{45}^{i} \tau_{r \theta}^{i}-\frac{\partial u_{r}^{i}}{\partial z}+\alpha_{13}^{i} T ; \\
& \frac{\partial u_{\theta}^{i}}{\partial r}=a_{45}^{i} \tau_{r z}^{i}+a_{44}^{i} \tau_{r \theta}^{i}+\frac{1}{r} u_{\theta}^{i}+\alpha_{23}^{i} T .
\end{aligned}
$$

The solution of the system (7) must correspond to the conditions on the side surfaces at $r=r_{1}, r=r_{2}$

$$
\begin{array}{lll}
\sigma_{r r}^{1}\left(r_{1}, z\right)= \pm q_{r}^{1}(z) ; & \tau_{r z}^{1}\left(r_{1}, z\right)=0 ; & \tau_{r \theta}^{1}\left(r_{1}, z\right)=0 ; \\
\sigma_{r r}^{2}\left(r_{2}, z\right)= \pm q_{r}^{2}(z) ; & \tau_{r z}^{2}\left(r_{2}, z\right)=0 ; & \tau_{r \theta}^{2}\left(r_{2}, z\right)=0,
\end{array}
$$

conditions at the ends are $z=0, z=L$ 


$$
\sigma_{z z}^{i}=u_{r}^{i}=u_{\theta}^{i}=0
$$

and the conditions of hard contact of the layers:

$$
\begin{array}{rll}
\sigma_{r r}^{i}\left(r_{i}\right)=\sigma_{r r}^{i+1}\left(r_{i}\right) ; & \tau_{r z}^{i}\left(r_{i}\right)=\tau_{r z}^{i+1}\left(r_{i}\right) ; & \tau_{r \theta}^{i}\left(r_{i}\right)=\tau_{r \theta}^{i+1}\left(r_{i}\right) ; \\
u_{r}^{i}\left(r_{i}\right)=u_{r}^{i+1}\left(r_{i}\right) ; & u_{z}^{i}\left(r_{i}\right)=u_{z}^{i+1}\left(r_{i}\right) ; & u_{\theta}^{i}\left(r_{i}\right)=u_{\theta}^{i+1}\left(r_{i}\right) .
\end{array}
$$

There is a diaphragm, which is absolutely rigid in its plane and flexible, at the edges of the cylinder in conditions (9). In (8) $q_{r}^{1}(z), q_{r}^{2}(z)-$ an internal and external pressure is distributed on the side surfaces of the shell, respectively.

To solve the three-dimensional problem (7) and (8-9), we use the BubnovGalerkin methodology. According to it, we decompose all functions into trigonometric series on the coordinate along the cylinder generatrix $z$, so that they would satisfy the boundary conditions (9):

$$
\begin{aligned}
& \sigma_{r r}^{i}(r, z)=\sum_{m=1}^{\infty}\left[y_{1}^{i},{ }_{p}(r)+y_{1}^{i /},{ }_{m}(r)\right] \sin l_{m} z ; \\
& \tau_{r z}^{i}(r, z)=\sum_{m=0}^{\infty}\left[y_{2}^{i},{ }_{p}(r)+y_{2}^{i /},{ }_{m}(r)\right] \cos l_{m} z ; \\
& \tau_{r \theta}^{i}(r, z)=\sum_{m=1}^{\infty}\left[y_{3}^{i}, p(r)+y_{3}^{i /},,_{m}(r)\right] \sin l_{m} z ; \\
& u_{r}^{i}(r, z)=\sum_{m=1}^{\infty}\left[y_{4}^{i},{ }_{p}(r)+y_{4}^{i /},,_{m}(r)\right] \sin l_{m} z ; \\
& u_{z}^{i}(r, z)=\sum_{m=0}^{\infty}\left[y_{5}^{i},{ }_{p}(r)+y_{5}^{i /},{ }_{m}(r)\right] \cos l_{m} z ; \\
& u_{\theta}^{i}(r, z)=\sum_{m=1}^{\infty}\left[y_{6}^{i}, p_{p}(r)+y_{6}^{i /},,_{m}(r)\right] \sin l_{m} z,
\end{aligned}
$$

where $y_{i},{ }_{p k}, y_{i}^{\prime},_{m k}(i=\overline{1,6})$ - are the components of expansion into trigonometric Fourier series of components of the stress-strain state of shell, $p, m-$ are the wave numbers in the series.

After some mathematical transformations and separation of variables in equations (7) using the ratios (11), we obtain for each i-th layer a system of differential equations of the twelfth order in the normal Cauchy form

$$
\frac{d \bar{y}^{i}}{d r}=T^{i}(r) \bar{y}^{i}+f^{i}, \quad T^{i}(r)=t_{n, l}^{i}(r), n, l=1 \div 12,
$$

where $\bar{y}^{i}=\left\{y_{1}^{i},{ }_{p} ; y_{2}^{i},{ }_{p} ; y_{3}^{i}, p ; y_{4}^{i}, p ; y_{5}^{i}, p ; y_{6}^{i},{ }_{p} ; y_{1}^{i /},{ }_{m} ; y_{2}^{i /},{ }_{m} ; y_{3}^{i /}, m_{m} ; y_{4}^{i /},{ }_{m} ; y_{5}^{i /},{ }_{m} ; y_{6}^{i /},{ }_{m}\right\}$ solving vector function. Non-zero elements of which are written in accordance with $[6,11], t_{n, l}^{i}(r)$ - coefficients for unknown systems (7), $f^{i}-$ the components of the stress-strain state related to the temperature in the system (7) and are determined as: 


$$
\begin{aligned}
& f_{1}^{i}=f_{7}^{i}=-\frac{b_{12}^{i}}{r} \alpha_{11}^{i} T-\frac{b_{22}^{i}}{r} \alpha_{22}^{i} T-\frac{b_{26}^{i}}{r} \alpha_{12}^{i} T ; f_{2}^{i}=f_{3}^{i}=f_{8}^{i}=f_{9}^{i}=0 \\
& f_{4}^{i}=f_{10}^{i}=\alpha_{33}^{i} T-a_{13}^{i} b_{11}^{i} \alpha_{11}^{i} T-a_{13}^{i} b_{12}^{i} \alpha_{22}^{i} T-a_{13}^{i} b_{16}^{i} \alpha_{12}^{i} T-a_{23}^{i} b_{12}^{i} \alpha_{11}^{i} T- \\
& -a_{23}^{i} b_{22}^{i} \alpha_{22}^{i} T-a_{23}^{i} b_{26}^{i} \alpha_{12}^{i} T-a_{36}^{i} b_{16}^{i} \alpha_{11}^{i} T-a_{36}^{i} b_{26}^{i} \alpha_{22}^{i} T-a_{36}^{i} b_{66}^{i} \alpha_{12}^{i} T ; \\
& f_{5}^{i}=f_{11}^{i}=\alpha_{13}^{i} T \\
& f_{6}^{i}=f_{12}^{i}=\alpha_{23}^{i} T .
\end{aligned}
$$

Implementation of the obtained one-dimensional problem on the stressstrain state of a thick-walled cylinder was carried out using the numerical method of discrete orthogonalization [3]. After solving the system (12) taking into account the boundary conditions (8), ratios (11) were used for the transition from the obtained functions to the components of the stress-strain state.

\section{Results of the numerical calculations and their analysis}

The object of the study is a cylindrical shell made of layers of fibrous boroplastic material and a layer of functionally graded material [16] under the distributed external pressure and external constant temperature. Silicone nitride was chosen as the ceramic component of FGMs, and titanium (Ti-6Al-4V) was chosen as the metal component. The temperature distribution along thickness of the cylinder was determined according to [9, 16]. Physical and mechanical properties of the functionally graded component of the cylinder dependent on the temperature were determined in the tables 1-4 [12] and according to the dependences [18]:

$$
\begin{aligned}
& E=P_{0 E} \cdot\left(P_{-1 E} T^{-1}+1+P_{1 E} T+P_{2 E} T^{2}+P_{3 E} T^{3}\right) ; \\
& v=P_{0 v} \cdot\left(P_{-1 v} T^{-1}+1+P_{1 v} T+P_{2 v} T^{2}+P_{3 v} T^{3}\right), \\
& \alpha=P_{0 a} \cdot\left(P_{-1 a} T^{-1}+1+P_{1 a} T+P_{2 a} T^{2}+P_{3 a} T^{3}\right) ; \\
& \kappa=P_{0 \kappa} \cdot\left(P_{-1 \kappa} T^{-1}+1+P_{1 \kappa} T+P_{2 \kappa} T^{2}+P_{3 \kappa} T^{3}\right),
\end{aligned}
$$

where $E-$ the desired modulus of elasticity, $v$ - Poisson's ratio, $\alpha-$ coefficient of linear thermal expansion and $\kappa$ - thermal conductivity, the given temperature $T\left({ }^{0} \mathrm{~K}\right)$, and $P_{0 E}, P_{0 v}, P_{0 a}, P_{0 \kappa}$ - the desired characteristics of the material, when $T=0^{0} \mathrm{~K}, P_{i E}, P_{i v}, P_{i a}, P_{i \kappa}$ - are given in the tables $1-4$.

Table 1

Modulus of elasticity of ceramics and metal, $\mathrm{Pa}$

\begin{tabular}{|c|c|c|c|c|c|}
\hline Material & $P_{0 E}$ & $P_{-1 E}$ & $P_{1 E}$ & $P_{2 E}$ & $P_{3 E}$ \\
\hline $\begin{array}{c}\text { Silicone } \\
\text { nitride }\end{array}$ & $348.43 * 10^{9}$ & 0 & $-3.070 * 10^{-4}$ & $2.160 * 10^{-7}$ & $-8.946 * 10^{-11}$ \\
\hline $\begin{array}{c}\text { Titanium } \\
\text { alloy } \\
(\text { Ti-6Al-4V) }\end{array}$ & $122.56 * 10^{9}$ & 0 & $-4.586 * 10^{-4}$ & 0 & 0 \\
\hline
\end{tabular}


Poisson's ratios of ceramics and metal

Table 2

\begin{tabular}{|c|c|c|c|c|c|}
\hline Material & $P_{0 v}$ & $P_{-1 v}$ & $P_{1 v}$ & $P_{2 v}$ & $P_{3 v}$ \\
\hline $\begin{array}{c}\text { Silicone } \\
\text { nitride }\end{array}$ & 0.24 & 0 & 0 & 0 & 0 \\
\hline $\begin{array}{c}\text { Titanium alloy } \\
\text { (Ti-6Al-4V) }\end{array}$ & 0.2884 & 0 & $1.121 * 10^{-4}$ & 0 & 0 \\
\hline
\end{tabular}

Table 3

Coefficient of linear thermal expansion of ceramics and metal, ${ }^{0} \mathrm{~K}^{-1}$

\begin{tabular}{|c|c|c|c|c|c|}
\hline Material & $P_{0 a}$ & $P_{-1 a}$ & $P_{1 a}$ & $P_{2 a}$ & $P_{3 a}$ \\
\hline $\begin{array}{c}\text { Silicone } \\
\text { nitride }\end{array}$ & $5.8723 * 10^{-6}$ & 0 & $9.095 * 10^{-4}$ & 0 & 0 \\
\hline $\begin{array}{c}\text { Titanium } \\
\text { alloy } \\
\text { (Ti-6Al-4V }\end{array}$ & $7.5788 * 10^{-6}$ & 0 & $6.638 * 10^{-4}$ & $-3.147 * 10^{-6}$ & 0 \\
\hline
\end{tabular}

Table 4

Thermal conductivity of ceramics and metal, $W /\left(\mathrm{m}^{0} \mathrm{~K}\right)$

\begin{tabular}{|c|c|c|c|c|c|}
\hline Material & $P_{0 \kappa}$ & $P_{-1 \kappa}$ & $P_{1 \kappa}$ & $P_{2 \kappa}$ & $P_{3 \kappa}$ \\
\hline $\begin{array}{c}\text { Silicone } \\
\text { nitride }\end{array}$ & 13.723 & 0 & $-1.032 * 10^{-3}$ & $5.466 * 10^{-7}$ & $-7.876 * 10^{-11}$ \\
\hline $\begin{array}{c}\text { Titanium alloy } \\
\text { (Ti-6Al-4V }\end{array}$ & 1.000 & 0 & $1.704 * 10^{-2}$ & 0 & 0 \\
\hline
\end{tabular}

Boroplastics has the following mechanical characteristics: $E_{11}=28 * 10^{5} \mathrm{MPa}, \quad E_{22}=E_{33}=3.1 * 10^{5} \mathrm{MPa}, \quad G_{12}=G_{23}=1.05 * 10^{5} \mathrm{MPa}$, $G_{13}=2.12 * 10^{5} \mathrm{MPa}, v_{21}=0,25, v_{12}=0,0277$.

Common characteristics of the functionally graded materials were determined in accordance with [8]:

$$
\begin{gathered}
E(\xi)=\left(E_{c}-E_{m}\right)(\xi / h)^{N}+E_{m} ; \\
v(\xi)=\left(v_{c}-v_{m}\right)(\xi / h)^{N}+v_{m} ; \\
\alpha(\xi)=\left(\alpha_{c}-\alpha_{m}\right)(\xi / h)^{N}+\alpha_{m} ; \\
\kappa(\xi)=\left(\kappa_{c}-\kappa_{m}\right)(\xi / h)^{N}+\kappa_{m},
\end{gathered}
$$

where $E(\xi), v(\xi), \alpha(\xi), \kappa(\xi)$ - physical and mechanical characteristics of the common material by thickness, $E_{m}, v_{m}, \alpha_{m}, \kappa_{m}$-mechanical characteristics of metal (titanium alloy), $E_{c}, v_{c}, \alpha_{c}, \kappa_{c}-$ mechanical characteristics of ceramics (zirconium), $h$ - the thickness of the functionally graded component of the shell material, $\xi$ - thickness coordinate $\xi=r-r_{1}, \quad r$ - the coordinate of an arbitrary point in the shell general coordinate system, fig. $1, r_{1}-$ the 
coordinate of the cylinder inner surface, $N$ - volume fraction of mixed materials [16].

A cylindrical shell with the following geometric parameters was considered (fig. 1): $L=1.2 \mathrm{~m}, r_{1}=0.57 \mathrm{~m}, r_{2}=0.63 \mathrm{~cm}, h=0.06 \mathrm{~m}$. Three variants of a thick-walled cylindrical shell were calculated. The first one took into the consideration only power load, and then combined power and thermal load. In this case, the temperature field changed only according to the thickness of the layer of functionally graded material.

In the first variant of this structure, it was assumed that the cylinder consists of two layers: the inner $r_{1}=0.57 \mathrm{~m}, r_{11}=0.6 \mathrm{~m}$ - made of boroplastic material with reinforcement angle $\psi=70^{\circ}$ to the axes $z$ and the external $r_{02}=0.6 \mathrm{~m}, r_{2}=0.63 \mathrm{~m}-$ made of functionally graded material, when $N=1$ (titanium alloy Ti-6Al-4V $\left(r_{02}\right)$ - silicone nitride $\left(r_{2}\right)$ ).

In the second variant, the shell was consisted of three layers: two internal cross-enclosed with reinforcement angles $\psi= \pm 70^{\circ}$ to the axis $z$, made of boroplastic material $r_{1}=0.57 \mathrm{~m}, r_{11}=0.585 \mathrm{~m}\left(\psi=70^{0}\right)$ and $r_{21}=0.585 \mathrm{~m}$, $r_{22}=0.6 \mathrm{~m}\left(\psi=-70^{0}\right)$ and external layer $r_{02}=0.6 \mathrm{~m}, r_{2}=0.63 \mathrm{~m}-$ made of functionally graded material, when $N=1$ (titanium alloy $\operatorname{Ti}-6 \mathrm{Al}-4 \mathrm{~V}\left(r_{02}\right)-$ silicone nitride $\left.\left(r_{2}\right)\right)$.

In the third variant, the shell was consisted of five layers: four internal cross-enclosed with reinforcement angles $\psi= \pm 70^{\circ}$ to the axis $z$, made of boroplastic material $r_{1}=0.57 \mathrm{~m}, r_{11}=0.5775 \mathrm{~m}\left(\psi=70^{\circ}\right)$ and $r_{21}=0.5775 \mathrm{~m}$, $r_{22}=0.585 \mathrm{~m}\left(\psi=-70^{0}\right), \quad r_{31}=0.585 \mathrm{~m}, \quad r_{32}=0.5925 \mathrm{~m} \quad\left(\psi=70^{\circ}\right)$ and $r_{41}=0.5925 \mathrm{~m}, r_{42}=0.6 \mathrm{~m}\left(\psi=-70^{0}\right)$ and the external layer $r_{02}=0.6 \mathrm{~m}$, $r_{2}=0.63 \mathrm{~m}-$ made of functionally graded material, when $N=1$ (titanium alloy Ti-6Al-4V $\left(r_{02}\right)$ - silicone nitride $\left.\left(r_{2}\right)\right)$.

All presented variants of shell structures were under pressure load that was distributed on the external surface $q=-q_{0} \sin (\pi z / l)$, where $q_{0}=100 \mathrm{MPa}$. In the case of joint power and thermal load, the temperature field changed only by the thickness of the functionally graded component of the material from $T=293^{0} \mathrm{~K}\left(20^{\circ} \mathrm{C}\right)$, when $r_{02}=0.6 \mathrm{~m}$, to $T=373^{0} \mathrm{~K}\left(100^{\circ} \mathrm{C}\right)$, when $r_{2}=0.63 \mathrm{~m}$ for all three variants of the cylindrical shell, and distributed by thickness according to the law presented in [9]

Fig. 2-4 show the change of stress-strain components of the shells with one layer of boroplastic, that is curve 1 (solid), with two and four layers, i.e curve 2 (dashed) and curve 3 (dotted), respectively. The calculation results are given by the coordinate $r$ for the cross-section that is on the middle of generatrix, i.e, when $z=0.5 L$. 


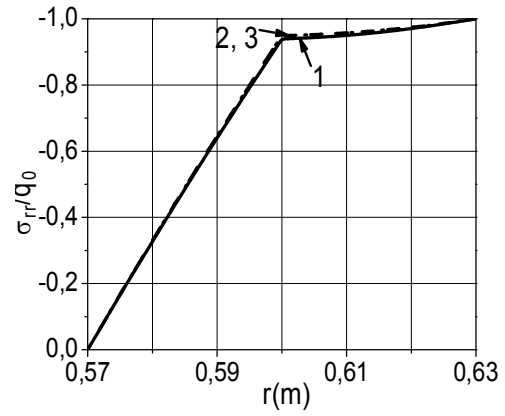

(a)

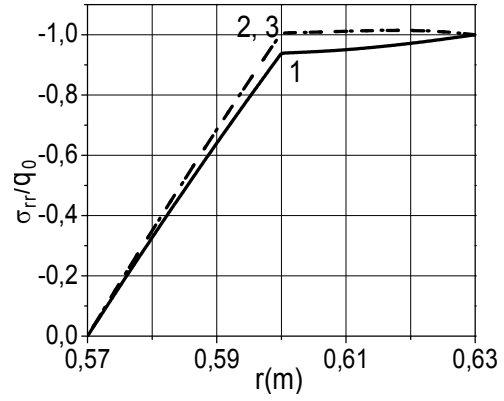

(b)

Fig. 2. Stress distribution $\sigma_{r r}$ by the thickness of the cylindrical shell:

(a) under the power load; (b) under power and thermal load

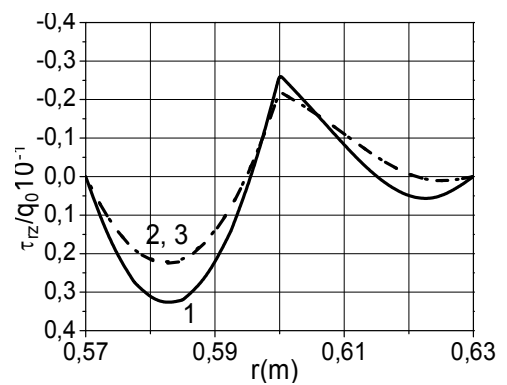

(a)

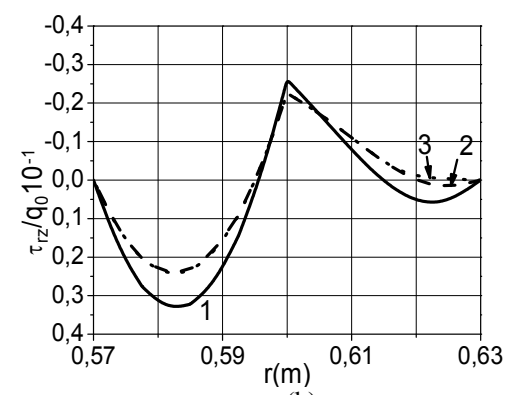

(b)

Fig. 3. Stress distribution $\tau_{r z}$ by the thickness of the cylindrical shell:

(a) under the power load; (b) under power and thermal load

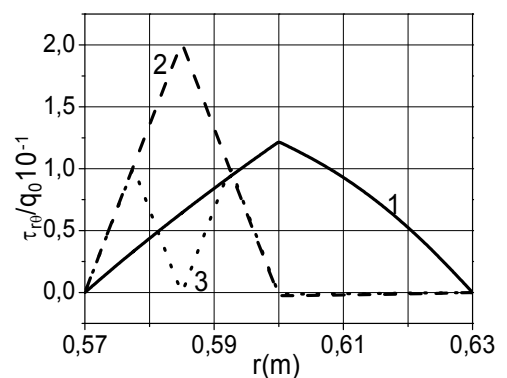

(a)

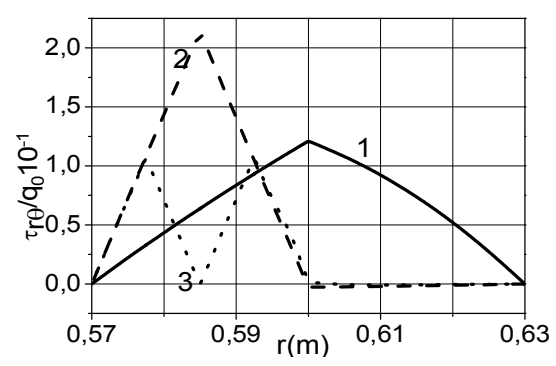

(b)

Fig. 4. Stress distribution $\tau_{r \theta}$ by the thickness of the cylindrical shell:

(a) under the power load; (b) under power and thermal load.

The analysis results of calculations in Fig. 2-4 describe the stress-strain state of the layered thick-walled anisotropic composite shells and show that the variable temperature field of the functionally graded component of the shell material within the studied temperatures ranges from $\mathrm{T}=293^{\circ} \mathrm{K}\left(20^{\circ} \mathrm{C}\right)$, when $r=0.6 \mathrm{~m}$ to $\mathrm{T}=373^{\circ} \mathrm{K}\left(100^{\circ} \mathrm{C}\right)$, when $r=0.63 \mathrm{~m}$ and does not significantly affect 
the stress-strain state of a thick-walled anisotropic cylinder. However, it should be noted that variable temperature field and distributed lateral pressure (fig. $2 \mathrm{~b}$ ) effects that the values of normal stresses are slightly, up to $5 \%$, higher compared with those, which are under power load only (fig. 2a).

The graphs presented in figs. $3 \mathrm{a}$ and $3 \mathrm{~b}$ indicate that the cross-laying of fibrous material allows reducing the value of the tangential stresses $\tau_{r z}$ compared to one layered of the composite. This is especially evident in the example of the thickness distribution of the tangential stresses $\tau_{r \theta}$ in figs. $4 \mathrm{a}$ and $4 \mathrm{~b}$, which appear only in anisotropic material. There are anisotropic components of the stress-strain state $\tau_{r \theta}$ for one composite layer in the transversely isotropic FGMs. However, for cross-ply composites having two and four layers the effect is almost absent.

\section{Conclusions}

In the article the numerical calculations of the stress-strain state of a thickwalled cylindrical anisotropic shell of fibrous composite material that is protected by a functionally graded material under power and thermal load, were conducted based on three-dimensional theory of elasticity. Variants of increasing the number of layers stacked so that their axes of orthotropy of fiber composites do not coincide with the axes of the cylinder coordinate system, creating the effect of a material with one plane of elastic symmetry, are analyzed. It is taken into account that the physical and mechanical properties of FGMs are dependent on temperature. It was found that the stress-strain state of a thick-walled anisotropic cylinder does not change significantly due to the action of high temperature, which is the effect of using FGMs to protect the cylindrical shell.

\section{REFERENCES}

1. Bazhenov V.A., Semeniuk M.P., Trach V.M. (2010), Nelinijne deformuvannia, stijkist' i zakrytychna povedinka anizotropnykh obolonok (Nonlinear deformation, stability and supercritical behavior of anisotropic shells). - Kyiv, Karavela, 352 p. [in Ukrainian].

2. Grigorenko Ya.M., Vasilenko A.T., Pankratova N.D. Zadachi teorii uprugosti neodnorodnyih tel (Problems of the theory of elasticity of inhomogeneous bodies) - Kyiv, Naukova dumka, 1991. - 216 p. [in Russian].

3. Grigorenko Ya.M., Kryukov N.N. Chislennyie resheniya zadach statiki gibkih sloistyih obolochek s peremennyimi parametrami (Numerical solutions of problems of statics of flexible layered shells with variable parameters) - Kyiv, Naukova dumka, 1988. - 264 p. [in Russian].

4. Lekhnitskyi S.G. Teoriya uprugosti anizotropnogo tela (The theory of elasticity of an anisotropic body). - 2nd ed. - Moscow: Nauka, 1977. - 415 p. [in Russian].

5. Novozhilov V.V. Osnovy nelineynoy teorii uprugosti (Fundamentals of the nonlinear theory of elasticity). - L.-M .: OGIZ, 1948. - 211 p. [in Russian].

6. Trach V.M., Podvorny A.V., Khoruzhiy M.M. Deformuvannya ta stiykist $\square$ netonkykh anizotropnykh obolonok (Deformation and stability of non-thin anisotropic shells): Monograph. - K.: Karavela, 2019. - 273 p. [in Ukrainian].

7. Trach V.M., Semenyuk M.P., Podvorny A.V. Vykorystannia 3D metodyky do rozrakhunku napruzhenoho stanu sharuvatykh anizotropnykh tsylindrychnykh obolonok pid diieiu bokovoho tysku. Resursoekonomni materialy, konstruktsii, budivli ta sporudy (The use of 3D techniques to calculate the stress state of layered anisotropic cylindrical shells under lateral 
pressure load). - Resource-saving materials, structures, buildings and constructions: Collection of scientific papers. Issue 37. - NUWEE.- Rivne, 2019.- P.296-306. [in Ukrainian].

8. Gibson L.J., Ashby M.F., Karam G.N., Wegst U., and Shercliff H.R. Mechanical properties of natural materials. II. Microstructures for mechanical efficiency, Proceedings of the Royal Society of London Series A, 450, 141-162.

9. Javaheri $R$. and Eslami M.R. Thermal buckling of functionally graded plates. AIAA Journal, 40, 2002, pp. 162-169

10. Podvornyi $A$. The stability of anisotropic cylindrical shells under torsion in spatial position. ActaSci.Pol. Arch. 19 (1) 2020, 103-109.

11. Podvornyi A.V., Semenyuk N.P., Trach V.M. Stability of inhomogeneous cylindrical shells under distributed external pressure in a three-dimensional statement // Int. Appl. Mech. 2017. - 53, N 6. P. $623-638$.

12. Reddy J.N. and Chin C.D. Thermoelastical analysis of functionally graded cylinders and plates, Journal of Thermal Stresses, 21, 593-626

13. Semenyuk, N.P., Trach, V.M., Podvornyi, A.V. Spatial Stability of Layered Anisotropic Cylindrical Shells Under Compressive Loads. International Applied Mechanics. №2, 2019.

14. Semenyuk, N.P., Trach, V.M., Podvornyi, A.V. Stability of cylindrical anisotropic shells under axial pressure in three-dimensional statement. Strength of Materials and Theory of Structures, issue 94, KNUBA (2015), pp. 192-206.

15. Shahsiah R. And Eslami M.R. Thermal buckling of functionally graded cylindrical shell, Journal of Thermal Stresses, 26, 2003, 277-294.

16. Shen, Hui-Shen Functionally graded materials: nonlinear analysis of plates and shells. - CRC Press Taylor \& Francis Group, Boca Raton London New York, 2009, - 266p.

17. Shen, Hui-Shen Postbuckling of axially-loaded FGM hybrid cylindrical shells in thermal environments, Composites Science and Technology, 65, 2005, 1675-1690.

18. Touloukian Y.S. Thermo physical Properties of High Temperature Solid Materials, McMillan, New York.

Стаття надійшла 13.05.2020

Семенюк М.П., Трач В.М., Подворний А.В.

\section{НАПРУЖЕНИЙ СТАН ТОВСТИХ АНІЗОТРОПНИХ ЦИЛІНДРИЧНИХ ОБОЛОНОК, ЗАХИЩЕНИХ ФУНКЦІОНАЛЬНО-ГРАДІЄНТНИМ МАТЕРІАЛОМ, ПІД ТЕРМОСИЛОВОЮ ДІЄЮ}

В роботі приведений напружений стан товстих конструктивно-анізотропних композитних циліндричних оболонок, що захищені функціонально-градієнтним матеріалом, і знаходяться в полі термосилової дії. На основі співвідношень просторової теорії пружності отримана система неоднорідних диференціальних рівнянь в тривимірній постановці, що описує напружений стан товстих анізотропних циліндрів. Для пониження розмірності зазначеної системи, використано аналітичний метод Бубнова-Гальоркіна. Отриману, таким чином, одновимірну систему з дванадцяти рівнянь нормального виду Коші реалізовано за використанням чисельного методу дискретної ортогоналізації. В якості представлення можливостей запропонованого підходу приведені напружені стани дво, чотири і п'ятишаруватих анізотропних циліндричних оболонок, утворених з волокнистих композитів, що захищені, від дії температури, шаром трансверсально-ізотропного функціональноградієнтного матеріалу.

Ключові слова: товста анізотропна циліндрична оболонка, напружений стан, тривимірна постановка, функціонально-градієнтний матеріал. 


\section{УДК 539.3}

Семенюк М.П., Трач В.М., Подворний А.В. Напружений стан товстих анізотропних циліндричних оболонок, захищених функціонально-градієнтним матеріалом, під термосиловою дісю // Опір матеріалів і теорія споруд: наук.-тех. збірн. - К.: КНУБА, 2020. - Вип. 105. - С. 165-178.

В роботі приведений напружений стан товстих конструктивно-анізотропних композитних циліндричних оболонок, що захищені функиіонально-градієнтним матеріалом, $i$ знаходяться в полі термосилової діі. На основі співвідномень просторової теорії пружності отримана система неоднорідних диференціальних рівнянь в тривимірній постановиі, що описує напружений стан товстих анізотропних циліндрів. Для пониження розмірності зазначеної системи, використано аналітичний метод Бубнова-Гальоркіна. Отриману, таким чином, одновимірну систему з дванадияти рівнянь нормального виду Коші реалізовано за використанням чисельного методу дискретної ортогоналізації. $B$ якості представлення можливостей запропонованого підходу приведені напружені стани дво, чотири і п'ятитарових анізотропних ииліндричних оболонок, утворених з волокнистих композитів, що захищені, від діï температури, шаром трансверсально-ізотропного функиіонально-градієнтного матеріалу.

Табл. 4. Іл. 1. Бібліогр. 18 назв.

\section{UDC 539.3}

Semenyuk M.P., Trach V.M., Podvornyi A.V. Stress-strain state of thick-walled anisotropic cylindrical shells under thermal power load, protected by the functionally graded material// Strength of Materials and Theory of Structures: Scientific-and-technical collected articles - Kyiv: KNUBA, 2020. - Issue 105. - P. 165-178.

In the article the stress-strain state of thick-walled structurally anisotropic composite cylindrical shells under thermal power load, which are protected by a functionally graded material, are analysed. Based on the interrelations of the spatial theory of elasticity, a system of inhomogeneous differential equations in three-dimensional formulation, which describes the stress-strain state of thick-walled anisotropic cylindrical shells, was obtained. To reduce the dimensionality of this system, the Bubnov-Galerkin analytical method was used. Thus, the obtained one-dimensional system of twelve equations of normal Cauchy form was implemented using the numerical method of discrete orthogonalization. To represent the possibilities of the proposed approach, there were used stress-strain states of two, four and five-layered anisotropic cylindrical shells of fibrous composites, protected from temperature by a layer of transversely isotropic functionally graded material.

Tabl. 4. Fig. 1. Ref. 18.

\section{УДК 539.3}

Семенюк М.П., Трач В.М., Подворный А.В. Напряженное состояние толстых анизотропных цилиндрических оболочек, защищенных функционально-градиентным материалом, под термосиловым действием// Сопротивление материалов и теория сооружений: науч.-техн. сборн. Вып. 105. - К.: КНУСА, 2020. - С. 165-178.

В работе приведено напряженное состояние толстых конструктивно-анизотропных композитных цилиндрических оболочек, защищенных функционально-градиентныли материалом, и находящихся в поле термосилового действия. На основе соотношений пространственной теории упругости получена система неоднородных дифференциальных уравнений в трехмерной постановке, описывающая напряженное состояние толстых анизотропных иилиндров. Для снижения размерности указанной системы, использован аналитический метод Бубнова-Галеркина. Полученная таким образом одномерная система из двенадцати уравнений нормального вида Коши реализована при использовании численного метода дискретной ортогонализации. $B$ качестве представления возможностей предложенного подхода приведены напряженные состояния двух, четырех и пятислойных анизотропных ичилиндрических оболочек, образованных из волокнистых композитов, защищеных, от действия температуры, слоем трансверсально-изотропного функиионально-градиентного материала.

Табл. 4. Ил. 1. Библиогр. 18 назв. 
Автор (науковий ступінь, вчене звання, посада): доктор технічний наук, професор, провідний науковий співробітник СЕМЕНЮК Микола Павлович

Адреса робоча: 02000 Україна, м. Київ, вул. Петра Нестерова, 3, Інститут механіки НАН України, СЕМЕНЮКУ Миколі Павловичу

Контактний тел. +38098-106-06-49

E-mail: mikolasem $@$ ukr.net

ORCID ID: http://orcid.org/0000-0001-5711-4277

Автор (науковий ступінь, вчене звання, посада): доктор технічний наук, професор, завідувач кафедри мостів і тунелів, опору матеріалів і будівельної механіки ТРАЧ Володимир Мирославович

Адреса робоча: 33028 Україна, м. Рівне, вул. Соборна, 11, Національний університет водного господарства та природокористування, ТРАЧУ Володимиру Мирославовичу

Контактний тел. +38097-289-15-80

E-mail: trach-vm@ukr.net

ORCID ID: http://orcid.org/0000-0001-9500-2743

Автор (науковий ступінь, вчене звання, посада): кандидат технічний наук, доцент кафедри мостів і тунелів, опору матеріалів і будівельної механіки ПОДВОРНИЙ Андрій Володимирович

Адреса робоча: 33028 Україна, м. Рівне, вул. Соборна, 11, Національний університет водного господарства та природокористування, ПОДВОРНОМУ Андрію Володимировичу

Контактний тел. +38096-411-12-87

E-mail: andrei_podvornyi@ukr.net

ORCID ID: http://orcid.org/0000-0001-8518-4395 